\title{
Effects of level soil bunds and stone bunds on soil properties and its implications for crop production: the case of Bokole watershed, Dawuro zone, Southern Ethiopia
}

\author{
Kebede Wolka ${ }^{1}$, Awdenegest Moges $^{2}$, Fantaw Yimer $^{1}$ \\ ${ }^{1}$ Wondo Genet College of Forestry and Natural Resources, Hawassa University, Shashemene, Ethiopia; Corresponding Author: \\ kebedewolka@gmail.com; fantawyimer2003@yahoo.com \\ ${ }^{2}$ Biosystems and Environmental Engineering Department, Hawassa University, Shashemene, Ethiopia; Corresponding Author: \\ awde_moges@yahoo.co.uk
}

Received 23 March 2011; revised 21 May 2011; accepted 31 July 2011.

\begin{abstract}
Level soil bunds (LSB) and stone bunds (SB) have been widely implemented in the Bokole watershed since 2000 through support of the World Food Program (WFP). However, the performance of them against the target of the structure has not been studied. This study analyzed the effects of LSB and SB on selected soil properties, when compared with nonterraced cropland. The Bokole watershed was divided into two units. From upper watershed, three croplands with LSB (aged 4, 6, and 9 years) and three nonterraced croplands each adjacent to one of the LSB were selected. Similarly, in lower watershed, SB aged 4, 6, and 8 years and three nonterraced croplands each adjacent to one of the SB were selected. From each cropland with LSB and SB, three composite soil samples (replicates) were collected systematically in $X$ designed rectangular plot. From each nonterraced cropland, three composite soil samples (replicates) were collected in $X$ designed square plot. A total of $\mathbf{3 6}$ soil samples were analyzed for Soil Organic Carbon (SOC), Total Nitrogen (TN), Available Phosphorus (AP), Available Potassium (AK), pH, and Cation Exchange Capacity (CEC) following standard laboratory procedures. Most soil parameters were not significantly different in cropland with LSB and SB compared to nonterraced. However, in LSB aged 4 years and SB aged 6 years AP and pH were significantly less than their adjacent-nonterraced cropland. In SB aged 8 years, SOC, AP, AK, and pH were also significantly less than adjacent-nonter-
\end{abstract}

raced cropland. Past erosion, and past land uses are likely factors contributed to the observed result. It was inferred that the mean contribution of LSB and SB alone for crop production with regard to analyzed soil parameters was not significant in the considered sites. Additional soil fertility management practices should be incorporated for better effect.

Keywords: Crop Yield; Level Soil Bund; Nonterraced; Soil Fertility; Stone Bund; Water Erosion; Watershed

\section{INTRODUCTION}

Human activity, such as conversion of forests to agricultural land, increased cultivation of marginal land, overgrazing, and low-input or fertility-mining methods of subsistence agriculture practiced on marginal lands with steep gradients; accelerate soil erosion [1-3]. The sorting action of erosion removes large proportions of the clay and humus from soil, leaving behind the less productive coarse sand, gravel, and in some case even stones, impairing the quality of the remaining topsoil [48]. The removal of this organic matter affects soil properties including texture, structure, nutrient availability and biological activity $[5,6]$ and makes soil more susceptible to further erosion as its aggregates becomes less stable [9] thus, negatively affecting crop production [1, 8-11]. In Ethiopia, measurements from experimental plots and micro-watersheds showed the annual soil loss from croplands is about $42 \mathrm{t} \cdot \mathrm{ha}^{-1} \cdot \mathrm{year}^{-1}$ [12]. As a consequence, the productive capacity of Ethiopia's highland soils is being reduced at an annual rate of $2 \%-3 \%$, which certainly contributes to a higher vulnerability to 
famine [13].

In the agricultural production system of the Ethiopian highlands, it is not possible to maintain year-round vegetation cover under given ecological, economic, and social circumstances $[8,14]$. According to these re- searchers, structures such as the stone bunds are an indispensable component of soil and water conservation (SWC) measures for the control of erosion. It was also reported that plots with stone bunds are more productive than those without such technologies in semi-arid areas. This is apparently due to the moisture conserving benefits of this technology being critical in drier areas [15]. Climate change, which alters precipitation patterns and intensities, is believed to substantially increase the risk of runoff, soil erosion, drought and other environmental problems. SWC measures such as soil bunds and stone bunds are adaptation options to mitigate the problems caused by climate change [16].

Since 2000 [17], government and nongovernment organizations such as World Food Programme (WFP) have been promoting agricultural production through environmental rehabilitation in the degraded Bokole watershed. Construction of level soil bunds and stone bunds have been the major program activities on the watershed croplands [17]. But the long-term effects of those interventions on production have not been investigated. This

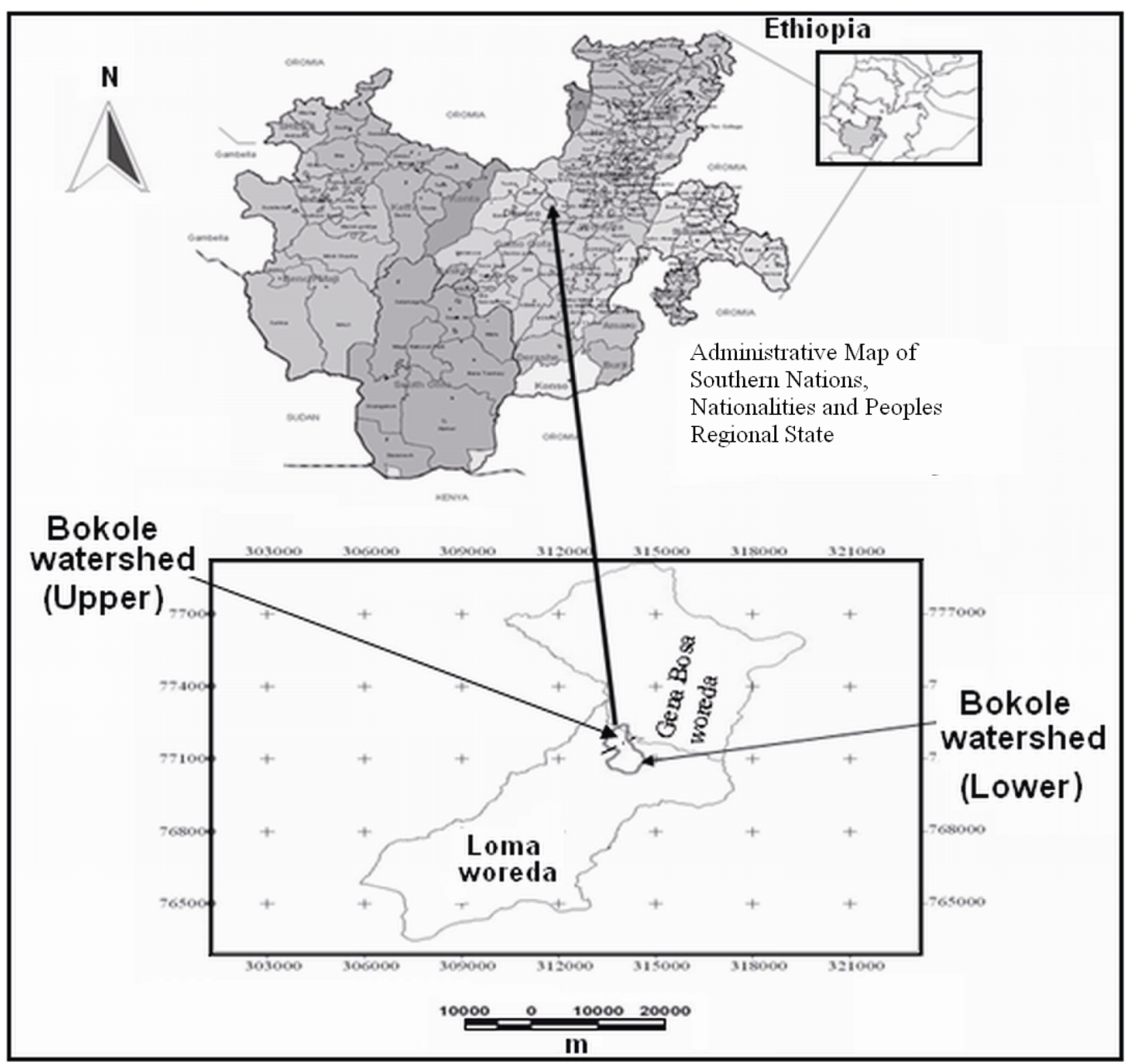

Figure 1. Location of the study site. 
study assessed the effects of Level Soil Bund (LSB) and Stone Bund (SB) on selected physical and chemical properties of soil.

\section{MATERIALS AND METHODS}

\subsection{Description of the Study Area}

The study area is situated in Southern Nations, Nationalities and Peoples Regional State (SNNPRS) of Ethiopia at Dawuro zone, Loma woreda. Geographically, it lies between $6^{\circ} 55^{\prime} \mathrm{N}$ and $7^{\circ} 01^{\prime} 30^{\prime \prime} \mathrm{N}$ latitude and $37^{\circ} 15^{\prime}$ $\mathrm{E}$ and $37^{\circ} 19^{\prime} \mathrm{E}$ longitude. It is at about $470 \mathrm{~km}$ in south west of Addis Ababa, the capital of Ethiopia. The study area topography is undulating and rugged (Figure 2). The watershed drains to the Omo River.

The study area lies between 1160 and $2300 \mathrm{~m}$ above sea level and receives $1400 \mathrm{~mm}-1600 \mathrm{~mm}$ rainfall annually. The mean temperature ranges from $15.1^{\circ} \mathrm{C}$ to $27.5^{\circ} \mathrm{C}$ [18]. The soil is grouped as Orthic Acrisols [18]. Mixed agriculture is the major economic activity in this watershed. The population of Bokole watershed is 11,798 (of which 3832 reside in the upper watershed and 7936 in the lower watershed) [19].

\subsection{Methodology}

Before soil sampling, two group discussions were conducted (one in upper watershed and the other in lower watershed, each comprises 10 farmers) with purposively selected farmers from different part of the watershed on effect of LSB and SB on soil properties. Individual farmers from whose land soil samples collected were thoroughly interviewed on observed changes as result of LSB and SB. Soil samples were collected from purposively selected croplands/plot with LSBs (aged 4, 6 and 9 years), SBs (aged 4, 6, and 8 years) and nonterraced (adjacent to each LSB and SB). The specific sampling sites were selected based on criteria: closeness of treated and nonterraced croplands (not too far from each other) [11]; age of the structure (4 - 9 years); number of inter-structure plots per treated cropland (more than or equal to 5); similarity of treated and adjacent-nonter-
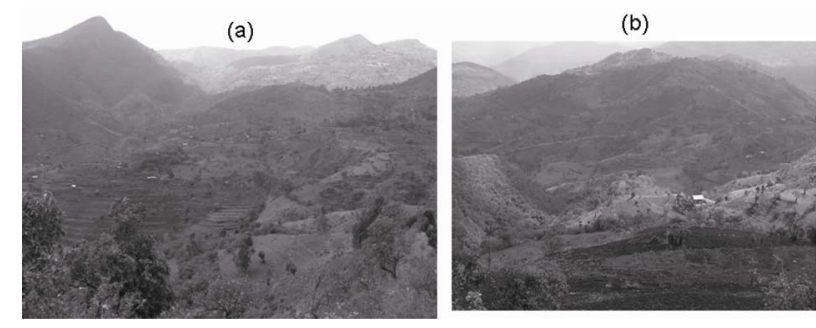

Figure 2. Partial view of the topography of the study site; Upper watershed (a) and lower watershed (b). raced croplands in certain management and natural set up. Croplands with LSBs were selected from upper watershed whereas croplands with SBs were selected from lower watershed because of the structures dominance. All the selected croplands have been under farmer management.

The sampling plots in LSB and SB were replicated three times systematically: the first, third and fifth plots (inter-structure area) in between two successive LSB and SB were selected in each treated cropland. From each sampling plot, a composite sample from the four corners and one at the center of an $\mathbf{X}$ designed rectangular plot were taken. The $\mathbf{X}$ designed rectangular plot has two sides along the contour with length of $15 \mathrm{~m}$ each and adjusted at $1.5 \mathrm{~m}$ away from LSBs and SBs [20]. By repeating those procedures on all the selected croplands with LSB and SB, a total of 18 composite samples (2 types of structures (LSB and SB) $\times 3$ croplands treated with each type of structures $\times 3$ inter-structure area or plot from each LSB and SB) were collected using auger from depth of $0-20 \mathrm{~cm}$.

From nonterraced croplands, three composite samples-replicates (from upper, middle and lower slope position within the field) were collected from $15 \mathrm{~m} \times 15$ $\mathrm{m} \mathbf{X}$ designed square plot. By repeating this procedures 18 ( 2 part of watershed that is upper and lower $\times 3$ croplands in each part of the watershed $\times 3$ sample per cropland) were taken using auger at $0-20 \mathrm{~cm}$ depth.

Each time after sampling (from treated and non-terraced), soil clods in samples was thoroughly broken to make a uniform mix in clean plastic bucket. The sample was divided in to four equal parts from which two diagonal parts were retained and other two removed. This was continued until sufficient sample was retained in the field. Samples were air dried at room temperature, homogenized and passed through a $2 \mathrm{~mm}$ sieve. Soil texture, Soil Organic Carbon (SOC), Total Nitrogen (TN), Available Phosphorus (AP), Available Potassium (AK), Soil $\mathrm{pH}(\mathrm{pH})$, and Cation Exchange Capacity (CEC) of the prepared samples were analyzed following standard laboratory procedure at City Government of Addis Ababa Environmental Protection Authority. T-tests were used to compare soil properties variation [21].

\section{RESULTS}

\subsection{Soil Physical and Chemical Properties}

The silt and clay fractions showed significant difference $(P<0.05)$ in croplands under LSB aged 6 year when compared with adjacent-nonterraced croplands while the LSBs aged 4 and 9 year was showed no significant difference in any fractions compared to adjacent-nonterraced cropland (Table 1). In the SB aged 4 
Table 1. Mean values $( \pm$ SEM) of sand, silt and clay fractions of topsoil $(0-20 \mathrm{~cm})$ from croplands with LSB aged 4, 6 , and 9 years and the respective adjacent-nonterraced (NTU) at the upper watershed $(n=3)$.

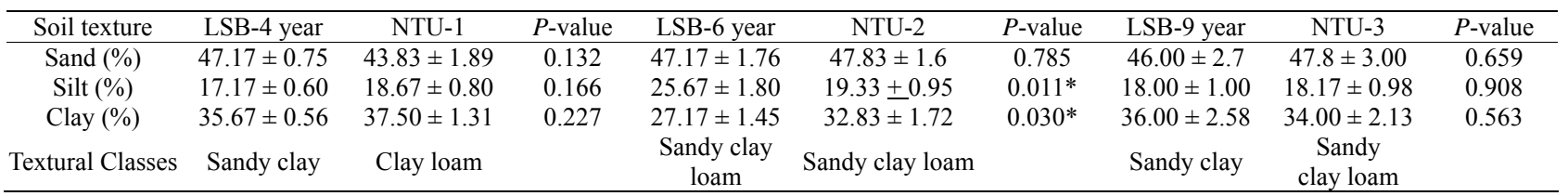

*denotes significantly different values from each other at $P<0.05$ by 2 -tailed t-test

Table 2. Mean values $( \pm \mathrm{SEM})$ of sand, silt and clay fractions of topsoil $(0-20 \mathrm{~cm})$ croplands with SB aged 4, 6, and 8 years and the respective adjacent-nonterraced (NTL) at the lower watershed $(n=3)$.

\begin{tabular}{|c|c|c|c|c|c|c|c|c|c|}
\hline Soil texture & SB-4 year & NTL-1 & $P$-value & SB-6 year & NTL- 2 & $P$-value & SB- 8 year & NTL- 3 & $P$-value \\
\hline Sand $(\%)$ & $55.67 \pm 1.31$ & $59.67 \pm 1.43$ & 0.066 & $49.17 \pm 1.40$ & $53.50 \pm 1.63$ & 0.071 & $48.67 \pm 2.12$ & $47.83 \pm 1.64$ & 0.763 \\
\hline Silt (\%) & $14.00 \pm 1.39$ & $16.83 \pm 0.60$ & 0.091 & $20.33 \pm 0.67$ & $17.33 \pm 0.95$ & $0.028 *$ & $23.67 \pm 1.61$ & $23.33 \pm 1.20$ & 0.871 \\
\hline Clay (\%) & $30.33 \pm 1.10$ & $23.50 \pm 1.34$ & $0.003 *$ & $30.5 \pm 1.18$ & $29.17 \pm 1.51$ & 0.503 & $27.67 \pm 0.95$ & $28.83 \pm 1.05$ & 0.429 \\
\hline Textural Classes & Sandy clay loam & Sandy clay loam & & $\begin{array}{c}\text { Sandy clay } \\
\text { loam }\end{array}$ & $\begin{array}{c}\text { Sandy clay } \\
\text { loam }\end{array}$ & & $\begin{array}{l}\text { Sandy clay } \\
\text { loam }\end{array}$ & Sandy clay loam & \\
\hline
\end{tabular}

*denotes significantly different values from each other at $P<0.05$ by 2 -tailed t-test

Table 3. Mean values $( \pm$ SEM) of SOC, TN, AP, AK, pH, and CEC of topsoil $(0-20 \mathrm{~cm})$ croplands with LSB aged 4, 6 , and 9 years and the respective adjacent-nonterraced (NTU) at the upper watershed $(n=3)$.

\begin{tabular}{cccccccccc}
\hline Soil parameters & LSB-4 year & NTU-1 & $P$-value & LSB-6 year & NTU-2 & $P$-value & LSB-9 year & NTU-3 & $P$-value \\
\hline SOC $(\%)$ & $1.23 \pm 0.15$ & $1.32 \pm 0.23$ & 0.736 & $1.41 \pm 0.28$ & $1.18 \pm 0.11$ & 0.463 & $1.57 \pm 0.27$ & $1.68 \pm 0.15$ & 0.715 \\
TN $(\%)$ & $0.11 \pm 0.02$ & $0.07 \pm 0.02$ & 0.275 & $0.21 \pm 0.13$ & $0.12 \pm 0.04$ & 0.515 & $0.08 \pm 0.02$ & $0.17 \pm 0.06$ & 0.138 \\
AP $(\mathrm{ppm})$ & $12.04 \pm 0.56$ & $16.87 \pm 1.94$ & $0.037 *$ & $5.86 \pm 0.95$ & $3.94 \pm 1.66$ & 0.131 & $10.5 \pm 2.70$ & $5.68 \pm 0.39$ & 0.105 \\
AK cmol (+)/kg soil) & $0.15 \pm 0.003$ & $0.21 \pm 0.04$ & 0.138 & $0.23 \pm 0.06$ & $0.31 \pm 0.13$ & 0.600 & $0.20 \pm 0.06$ & $0.14 \pm 0.004$ & 0.326 \\
pH & $5.26 \pm 0.15$ & $5.64 \pm 0.04$ & $0.034^{*}$ & $5.87 \pm 0.10$ & $5.34 \pm 0.23$ & 0.068 & $5.83 \pm 0.07$ & $5.93 \pm 0.08$ & 0.383 \\
CEC cmol (+)/kg soil) & $20.57 \pm 2.63$ & $29.75 \pm 3.48$ & 0.062 & $17.16 \pm 2.10$ & $21.27 \pm 4.03$ & 0.380 & $16.75 \pm 1.57$ & $18.33 \pm 1.53$ & 0.487 \\
\hline
\end{tabular}

*denotes significantly different values from each other at $P<0.05$ by 2 -tailed t-test

Table 4. Mean values $( \pm$ SEM) of SOC, TN, AP, AK, pH, and CEC of topsoil $(0-20 \mathrm{~cm})$ croplands with SB aged 4, 6, and 8 years and the respective adjacent-nonterraced (NTL) at the lower watershed $(n=3)$.

\begin{tabular}{|c|c|c|c|c|c|c|c|c|c|}
\hline Soil parameters & SB-4 year & NTL- 1 & $P$-value & SB-6 year & NTL-2 & $P$-value & SB-8 year & NTL-3 & $P$-value \\
\hline SOC (\%) & $1.57 \pm 0.16$ & $1.22 \pm 0.12$ & 0.101 & $1.35 \pm 0.14$ & $1.10 \pm 0.12$ & 0.206 & $0.69 \pm 0.11$ & $1.01 \pm 0.09$ & $0.048 *$ \\
\hline $\mathrm{TN}(\%)$ & $0.28 \pm 0.08$ & $0.13 \pm 0.03$ & 0.098 & $0.09 \pm 0.06$ & $0.06 \pm 0.02$ & 0.619 & $0.41 \pm 0.13$ & $0.26 \pm 0.12$ & 0.409 \\
\hline $\mathrm{AP}(\mathrm{ppm})$ & $2.92 \pm 0.65$ & $4.41 \pm 0.46$ & 0.089 & $1.82 \pm 0.13$ & $7.33 \pm 1.74$ & $0.010 *$ & $10.62 \pm 1.71$ & $27.48 \pm 6.20$ & $0.026^{*}$ \\
\hline AK cmol (+)/kg soil) & $0.45 \pm 0.08$ & $0.44 \pm 0.02$ & 0.906 & $1.39 \pm 0.30$ & $0.83 \pm 0.15$ & 0.123 & $0.59 \pm 0.29$ & $1.61 \pm 0.32$ & $0.039 *$ \\
\hline $\mathrm{pH}$ & $7.06 \pm 0.034$ & $7.13 \pm 0.02$ & 0.090 & $6.34 \pm 0.05$ & $6.63 \pm 0.087$ & $0.014^{*}$ & $6.41 \pm 0.08$ & $6.64 \pm 0.04$ & $0.03 *$ \\
\hline $\mathrm{CEC} \mathrm{cmol}(+) / \mathrm{kg}$ soil) & $25.70 \pm 5.85$ & $21.80 \pm 5.19$ & 0.629 & $30.43 \pm 4.46$ & $31.43 \pm 3.52$ & 0.864 & $31.57 \pm 2.96$ & $25.93 \pm 6.85$ & 0.468 \\
\hline
\end{tabular}

*denotes significantly different values from each other at $P<0.05$ by 2 -tailed t-test

year, significantly greater clay content was observed as compared to its adjacent-nonterraced cropland. Tables 3 and $\mathbf{4}$ shows result for soil chemical properties analysis.

\section{DISCUSSIONS}

\subsection{Soil Properties in Croplands with SWC Structures and Nonterraced}

In the study site, SOC was generally less in soils of the study area which might be due to the practices such as intensive tillage, continuous cropping, removal of crop residues, and low organic carbon input in croplands.
[20] mentioned that SOC values are typically low in the Ethiopian highlands as a consequence of stubble grazing and the absence of fallowing.

The soil and water conservation system of LSB and SB reduce surface runoff and soil loss, retain water that enhances crop growth and contributes to SOC input. Despite these all benefits, in most comparison no significant difference in SOC observed. Even it was significantly low $(P<0.05)$ in SB aged 8 year compared to adjacent-nonterraced. This result showed that type and intensity of other land management practices that individual farmers adapted in the past has also role in current level of SOC. The report by [22] around the Mediterra- 
nean region indicated SOC significantly differ was not agree with result of present study in that 50 years old stone-walled terrace was compared to nonterraced.

AP was significantly high $(P<0.05)$ in nonterraced croplands adjacent to LSB aged 4 year, SB aged 6 year and SB aged 8 year. These were perhaps due to: the difference in the past land degradation resulting from continuous cultivation, extractive plant harvest and soil erosion. Similar study by [23] in Anjeni watershed (Ethiopia) also showed that AP on nonterraced land was higher than the terraced.

The relatively higher AK on nonterraced cropland adjacent to SB aged 8 year was most likely because of the difference in weathering process and past erosion. The significantly low $(P<0.05)$ soil $\mathrm{pH}$ in LSB aged 4 year, in SB aged 6 year and SB aged 8 year compared to the respective adjacent-nonterraced cropland were probably due to loss of relatively more basic cation resulted from erosion before the structures built and did not restore yet after the structures. Under a continuous cropping system soil acidity increases due to the gradual replacement of basic cations by aluminum [24]. Even though soil acidification is natural process involved in soil formation [7], it is influenced by historic land use practice and subsequent soil erosion.

\subsection{Relating Soil Analysis and Farmers' Opinion}

The LSB and SB have been accepted and introduced to reduce soil loss by creating barrier against surface runoff and reducing slope length and gradient in the long-term. Farmers in thorough group discussion indicated that structures improved crop yield. Those farmers whose land the soil sample were taken also perceived that the structure has improved crop yield when compared to previous situation. However, most of the selected chemical properties in cropland with structures were not significantly higher than adjacent nonterraced. Even for AP, pH, SOC, and AK in some sites, they have been significantly less than nonterraced cropland. This can be explained by the fact that, on one hand, natural resource experts recommend the structures when the croplands become degraded. Farmers also initially accept the structure when the land gets relatively denuded and thus it takes time for soil to restore in the pace of less or no additional soil fertility management. Reference [25] stated adoption of the SWC technologies is likely to increase, among other things, with recognition of the erosion problem and slope gradient. The traditional diversion ditches that have commonly been constructed on nonterraced cropland to expel surface runoff and to reduce erosion might also have contributed for reduction of erosion and subsequent effect on nonter- raced croplands. Past land use and management and past erosion and deposition also determine the current property of soil.

SWC structures are practically used as support for agronomic and soil management [26] and considered as the first defense line. Thus, they alone are less likely to improve soil properties significantly under similar management to nonterraced. Reference [27] has reported that combining stone rows barriers to run-off with the application of compost was significantly controlled erosion and reduced organic $\mathrm{C}$ and nutrient losses than compost or stone row alone. Related experimental study in Burkina Faso [24] showed that stone lines, five years after laying, have a limited effect on soil fertility and a drop in soil $\mathrm{pH}$, organic $\mathrm{C}, \mathrm{N}$, and $\mathrm{P}$ concentrations were observed. Similarly, experiment in Maybar research site of Ethiopia [14] on level soil bund without any agronomic or biological techniques showed decrease in production during the first 3 - 5 years, which showed probably no improvement in soil fertility.

SWC structures such as stone bund traps finer soil particles that were eroded by rain water and tillage from inter-structure area. Thus fertile soil remains on the structure and nearby at upslope side. On hand it might be partly due to this reason that eight years after construction of LSB showed significantly less in most analyzed nutrient concentration for sampled plot $(1.5 \mathrm{~m}$ away from structure) when compared with nonterraced.

The in-depth interview and discussion in the present study watershed revealed that the respondents have positive attitudes towards introduced SWC structures by observing mainly crop performance [28]. This could probably be due to the fact that crop performance is not only function of soil fertility but also due to water availability, which most likely improved by water retention ability of structures as observed by farmers. The explanation by [29] confirms that evaluating soil fertility by crop yield alone is not fair because crop performance is a function of many factors including soil nutrient (fertility) itself, soil water availability, and weed competition

\section{CONCLUSIONS AND RECOMMENDATION}

Even though farmers perceived some improvements on cropland after construction of SWC structures by using their own criteria, the standard soil laboratory analysis from croplands with LSB and SB and nonterraced did not show remarkable difference for some parameters and even less for some sites. Thus, without withstanding the contribution of structures in reducing surface runoff and erosion which is partially the conesquences of climate change, it can be concluded that the contribution of LSB and SB alone with regard to im- 
proving soil properties for crop production are not significant compared to nonterraced cropland in the considered site. The perceived improvement in crop production was most likely due to water retention ability of the structures which contributes for adaptation of climate change.

It can be inferred that soil nutrient restoration for degraded land takes long time in the pace of continuous cultivation and poor soil fertility management. It was also suspected that most of soil along with nutrient trapped by the structures deposited on the structure and adjacent to it at distance range of $1.5 \mathrm{~m}$ in upslope area.

To make watershed management particularly LSB and SB effective for attaining and sustaining food security in smallholder farming, soil fertility management practices such as use of crop residue and manuring are recommended beside the structures in the study area. The role and effectiveness of traditional diversion ditch, which has commonly been practiced on nonterraced cropland, in alleviating soil erosion should be studied.

\section{ACKNOWLEDGEMENTS}

The Center for Environment and Society project (at Hawassa University), Food for Work project (in SNNPRS, Agriculture and Rural Development Bureau), and Wondo Genet College of Forestry and Natural Resources, Hawassa University, are gratefully acknowledged for the financial support.

\section{REFERENCES}

[1] Lal, R. (1996) Deforestation and land-use effects on soil degradation and rehabilitation in western Nigeria. III. Runoff, soil erosion and nutrient loss. Land Degradation \& Development, 7, 99-119. doi:10.1002/(SICI)1099-145X(199606)7:2<99::AID-LD R220>3.0.CO;2-F

[2] Osman, M. and Sauerborn, P. (2001) Soil and water conservation in Ethiopia: Experience and lessons. Journal of Soil and Sediment, 1, 117-122. doi:10.1007/BF02987717

[3] McConchie, J.A and Huan-Cheng, M.A (2002) A discussion of the risks and benefits of using rock terracing to limit soil erosion in Guizhou Province. Journal of Forestry Research, 13, 41-47. doi:10.1007/BF02857144

[4] Troeh, F.R., Hobbs, A.J. and Danahue, R.L. (1980) Soil and water conservation for productivity and environmental protection. Prentice-Hall, Englewood Cliffs.

[5] Young, A. (1997) Agroforestry for soil management. 2nd Edition. CAB International, Wallingford.

[6] Lowery, B., Hart, G.L., Bradford, J.M., Kung, K.-J.S. and Huang, C. (1999) Erosion impacts on soil quality and properties and model estimates of leaching potentials. In: Lal, R., Ed., Soil Quality and Soil Erosion, Soil and Water Conservation Society, Ankeny.

[7] Brady, N. and Weil, R. (2002) The nature and properties of soils. 13th Edition. Pearson Education, Upper Saddle River.

[8] Ludi, E. (2004) Economic analysis of soil conservation:
Case studies from the Highlands of Amhara region, Ethiopia. African Studies Series A18. Geographical Bernensia, Bernee.

[9] Norton, D., Shainberg, I., Cihacek, L. and Edwards, J.H. (1999) Erosion and soil chemical properties. In: Lal, R. Ed., Soil Quality and Soil Erosion, Soil and Water Conservation Society, Ankeny.

[10] Olson, K.R., Mokma, D.L., Lal, R., Schumacher, T.E. and Lindstrom, M.J. (1999) Erosion impacts on crop yield for selected soils of the North central United States. In: Lal, R., Ed., Soil Quality and Soil Erosion, Soil and Water Conservation Society, Ankeny.

[11] Alemayehu, M., Yohannes, F. and Dubale, P. (2006) Effects of Indigenous stone bunding $(\mathrm{Kab})$ on crop yield at Mesobit-gedeba, north Shoa, Ethiopia. Land degradation and Development, 17, 45-54. doi:10.1002/1dr.693

[12] Wagayehu, B. and Drake, L. (2003) Soil and water conservation decision behavior of subsistence farmers in the Eastern Highlands of Ethiopia: A case study of the Hunde-Lafto area. Ecological Economics, 46, 437-451. doi:10.1016/S0921-8009(03)00166-6

[13] Admasu, A. (2005) Study of sediment yield from the Watershed of Angereb reservoir. M.Sc thesis, Department of Agricultural Engineering, Alemaya University, Ethiopia.

[14] Herweg, K. and Ludi, E. (1999) The performance of selected soil and water conservation measures: Case studies from Ethiopia and Eritrea. Catena, 36, 99-114. doi:10.1016/S0341-8162(99)00004-1

[15] Kassie, M., Yesuf, M. and Mulugeta, E. (2007) Impact of soil conservation on crop production in the northern Ethiopian Highlands. IFPRI Discussion Paper 00733, International Food Policy Research Institute, Washington.

[16] Kato, E., Ringler, C., Yesuf, M. and Bryan, E. (2009) Soil and water conservation technologies: A buffer against production risk in the face of climate change? Insights from the Nile Basin in Ethiopia. IFPRI Discussion Paper 00871 . http://www.ifpri:publication. Date accessed 03/11/2010

[17] OoARD (2009) Soil and water conservation report. Loma woreda office of Agriculture and Rural Development, Gessa, Ethiopia.

[18] SNNPRS-BoFED (2004) Regional atlas. Southern Nation, Nationalities and Peoples Regional State, Bureau of Finance and Economic Development, Bureau of Statistics and Population, Awassa, Ethiopia.

[19] OoARD (2008) Population of Lomma woreda by Kebele. Lomma Woreda Office of Agriculture and Rural Development, Gessa, Ethiopia.

[20] Vancampenhout, K., Nyssen, J., Desta, G., Deckers, J., Poesen, J., Mitiku, H. and Moeyersons, J. (2005) Stone bunds for soil conservation in the northern Ethiopian highlands: Impacts on soil fertility and crop yield. Soil and Tillage Research, 90, 1-15. doi:10.1016/j.still.2005.08.004

[21] SPSS Inc (2003) SPSS for Window Brief Guide.

[22] Hammad, A.H.A., Børresen, T. and Haugen, L.E. (2005) Effects of rain characteristics and terracing on runoff and erosion under the Mediterranean. Soil \& Tillage Research, 87, 39-47. doi:10.1016/j.still.2005.02.037

[23] Alemayehu Assefa (2007) Impact of terrace development and management on soil properties in Anjeni area, West 
Gojam. M.Sc thesis, Addis Ababa University, Ethiopia.

[24] Zougmore, R., Gnankambary, Z., Guillobez, S. and Stroosnijder, L. (2002) Effects of stone lines on soil chemical characteristics under continuous sorghum cropping in semiarid Burkina Faso. Soil and Tillage Research, 66, 47-53. doi:10.1016/S0167-1987(02)00012-0

[25] Bekele, S. and Holden, S.T. (1998) Resource degradation and adoption of land conservation technologies in the Ethiopian Highlands: A case study in Andit Tid, North Shewa. Agricultural Economics, 18, 233-247. doi:10.1016/S0169-5150(98)00036-X

[26] Morgan R.P.C (2005) Soil erosion and conservation. $3^{\text {rd }}$ Edition. Blackwell Science Ltd, Oxford.

[27] Zougmoré, R., Mando, A. and Stroosnijder, L. (2009)
Soil nutrient and sediment loss as affected by erosion barriers and nutrient source in Semi-Arid Burkina Faso. Arid Land Research and Management, 23, 85-101.

[28] Wolka, K., Moges, A. and Yimer, F. (2010) Farmers' perception of effects of soil and water conservation structures on crop production: the case of Bokole watershed, Dawuro zone, southern Ethiopia. Unpublished Manuscript, Wondo Genet College of Forestry and Natural Resources, Hawassa University, Ethiopia.

[29] Shemdoe, R.S., Kikula, I.S. Damme, P.V. and Cornelis, W.M. (2009) Tillage practices and their impacts on soil fertility in farmers' fields in Semi-Arid Central Tanzania. Arid Land Research and Management, 23, 168-181. doi:10.1080/15324980902817121 